\title{
Test Plan for Long-Term Operation of a Ten-Cell High Temperature Electrolysis Stack
}

\author{
James E. O'Brien \\ Carl M. Stoots \\ J. Stephen Herring \\ July 2008
}

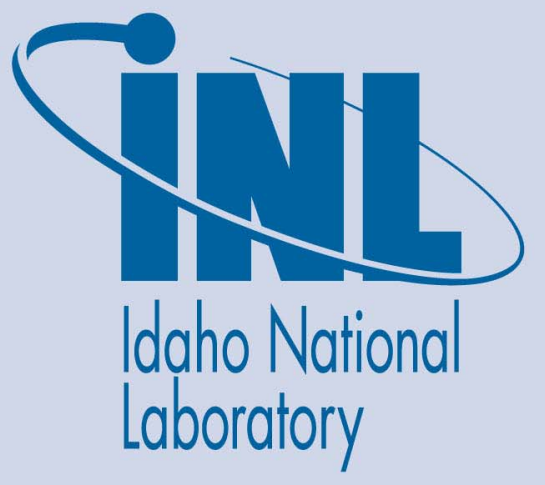

The INL is a U.S. Department of Energy National Laboratory operated by Battelle Energy Alliance 


\title{
Test Plan for Long-Term Operation of a Ten-Cell High Temperature Electrolysis Stack
}

\author{
James E. O'Brien \\ Carl M. Stoots \\ J. Stephen Herring
}

July 2008

\begin{abstract}
Idaho National Laboratory
Idaho Falls, Idaho 83415
\end{abstract}

http://www.inl.gov

Prepared for the

U.S. Department of Energy

Office of Nuclear Energy

Under DOE Idaho Operations Office

Contract DE-AC07-05ID14517 


\section{DISCLAIMER}

This information was prepared as an account of work sponsored by an agency of the U.S. Government. Neither the U.S. Government nor any agency thereof, nor any of their employees, makes any warranty, express or implied, or assumes any legal liability or responsibility for the accuracy, completeness, or usefulness of any information, apparatus, product, or process disclosed, or represents that its use would not infringe privately owned rights. References herein to any specific commercial product, process, or service by trade name, trademark, manufacturer, or otherwise, does not necessarily constitute or imply its endorsement, recommendation, or favoring by the U.S. Government or any agency thereof. The views and opinions of authors expressed herein do not necessarily state or reflect those of the U.S. Government or any agency thereof. 


\section{ABSTRACT}

This document defines a test plan for a long-term (2500 Hour) test of a ten-cell high-temperature electrolysis stack to be performed at INL during FY09 under the Nuclear Hydrogen Initiative. This test was originally planned for FY08, but was removed from our work scope as a result of the severe budget cuts in the FY08 NHI Program. The purpose of this test is to evaluate stack performance degradation over a relatively long time period and to attempt to identify some of the degradation mechanisms via post-test examination. This test will be performed using a planar ten-cell Ceramatec stack, with each cell having dimensions of $10 \mathrm{~cm} \times 10 \mathrm{~cm}$. The specific makeup of the stack will be based on the results of a series of shorter duration ten-cell stack tests being performed during FY08, funded by NGNP. This series of tests was aimed at evaluating stack performance with different interconnect materials and coatings and with or without brazed edge rails. The best performing stack from the FY08 series, in which five different interconnect/coating/edge rail combinations were tested, will be selected for the FY09 long-term test described herein. 


\section{TABLE OF CONTENTS}

ABSTRACT

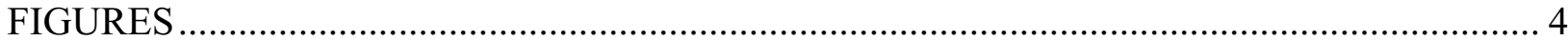

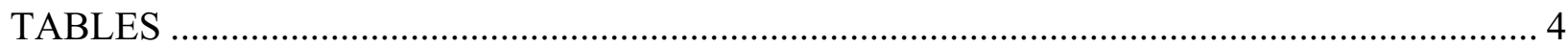

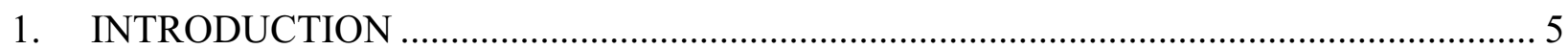

2. APPARATUS AND PROCEDURE ........................................................................... 5

2.1. Short Stack HTE Test Apparatus............................................................................ 5

2.2. Short Stack HTE Test Procedure .............................................................................. 10

3. TEST CONDITIONS FOR 2500 HOUR LONG-TERM TEST .................................. 11

3.1. TEST STARTUP SEQUENCE …....................................................................... 11

3.2. TEST MATRIX (based on estimated per-cell ASR value of $1.5 \mathrm{Ohm} \cdot \mathrm{cm}^{2}$ ) ................. 13

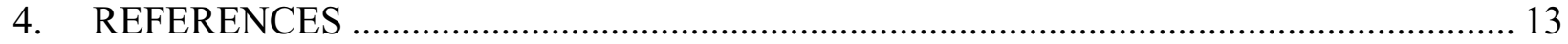

\section{FIGURES}

Figure 1. Schematic of experimental apparatus for electrolysis stack testing................. 6

Figure 2. High-temperature electrolysis hardware .................................. 7

Figure 3. Detail of 10 -cell stack............................................... 8

Figure 4. Interconnect plate and single electrolysis cell $\ldots \ldots \ldots \ldots \ldots \ldots \ldots \ldots \ldots \ldots \ldots \ldots \ldots$

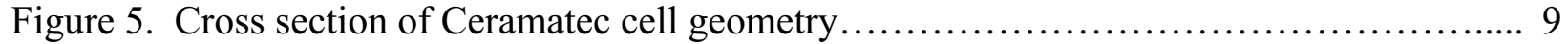

Figure 6 . Ten-cell stack mounted on fixture for testing at INL $\ldots \ldots \ldots \ldots \ldots \ldots \ldots \ldots \ldots \ldots \ldots$

\section{TABLES}

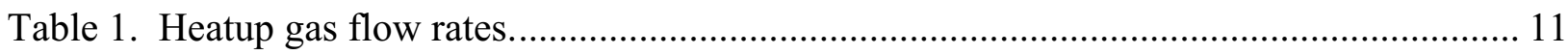

Table 2. Operating conditions for initial sweeps and long-term testing................................ 13 


\section{INTRODUCTION}

The primary objective of the INL High-Temperature Electolysis (HTE) project is to develop and demonstrate HTE for efficient hydrogen production using solid-oxide electrolysis cells. In terms of technology development, one of the major research issues associated with HTE is cell performance degradation that occurs during long-term operation. Various mechanisms for cell degradation have been postulated including chromia and silica transport with subsequent poisoning of electrodes, morphology change (coarsening) of porous electrodes in the triple phase boundary region, blocking the electrochemical reaction sites, delamination of electrodes from electrolytes, interconnect oxidation and subsequent increased resistance across oxide scales, electrolyte phase instabilities, and others [1].

The objective of long-term testing is to characterize the long-term performance of solid-oxide electrolysis cells (SOEC) in a stack configuration and to try to diagnose degradation mechanisms via post-test examination. This particular test will focus on evaluating the performance of a short 10-cell Ceramatec stack that will be fabricated with the best-performing material set available at the time of the test. The material set decision will be based on a series of five tests performed during FY08. Three of these tests were performed at Ceramatec and two at INL. The FY08 test matrix was as follows:

1. 10 cell stack with Crofer22 separator plates and Supplier-developed coatings

2. 10 cell stack with alloy 441 separator plates and Supplier-developed coatings

3. 10 cell stack with Crofer22 separator plates and spinel coatings

4. 10 cell stack with alloy 441 separator plates and spinel coatings

5. 10 cell stack with edge rail brazing variation (vacuum/hydrogen, fiberfrax/apal refractory setter material)

As this test plan is being written, the stack with the Crofer22 interconnects and spinel coatings has exhibited the best performance.

\section{APPARATUS AND PROCEDURE}

\subsection{Short Stack HTE Test Apparatus}

A schematic of the small-stack-testing apparatus to be used for this test is presented in Fig. 1. A photograph of the experimental hardware is provided in Fig. 2. Primary hardware components include gas supply cylinders, gas mass-flow controllers, a humidifier, dewpoint measurement stations, temperature and pressure measurement, high temperature furnace, and a solid oxide electrolysis stack. Nitrogen was used as an inert carrier gas. The use of a carrier gas allows us to independently vary both the partial pressures and the flow rates of the steam and hydrogen gases while continuing to operate at atmospheric pressure. The flow rates of nitrogen, hydrogen and air are established by means of precision mass-flow controllers (Hastings Model HFC-302, with Hastings Model 400 electronics). Air flow to the stack is supplied by the laboratory shop air system, after passing through a two-stage extractor / dryer unit. 


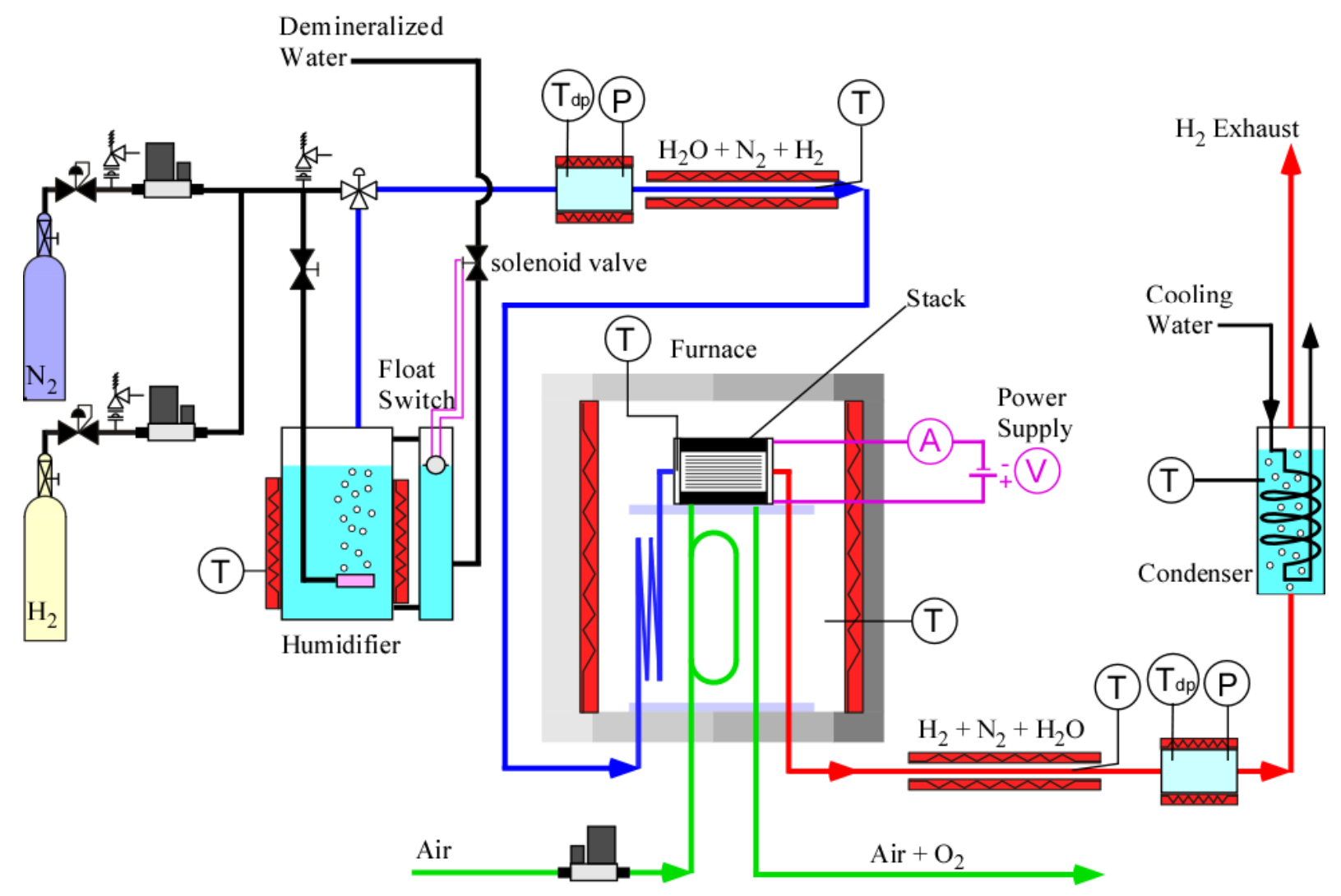

Figure 1. Schematic of experimental apparatus for electrolysis stack testing.

Downstream of the mass-flow controller, nitrogen is mixed with a smaller flow of hydrogen gas. Hydrogen is included in the inlet flow as a reducing gas in order to help prevent oxidation of the nickel cermet electrode material. The nitrogen/ hydrogen gas mixture is mixed with steam by means of a heated humidifier. The humidifier (visible in Fig. 1) consists of a heated stainlesssteel vessel containing demineralized / deionized water through which the nitrogen / hydrogen flow is bubbled. A stainless-steel sparger was used for this purpose. Demineralized water is fed to the humidifier via a solenoid valve that automatically opens whenever the liquid water level in the humidifier drops below a fixed level. The action of the solenoid valve is controlled by a float switch, as depicted in the schematic.

The dewpoint temperature of the nitrogen / hydrogen / steam gas mixture exiting the humidifier is monitored continuously using a precision dewpoint sensor (Vaisala Model HMP247). These measurements have indicated that the dewpoint temperature of the gas mixture leaving the humidifier is very close to the water bath temperature, but not necessarily equal to it. The humidifier is fitted with a clamp heater and is externally insulated. The temperatures of both the humidifier wall and the water bath are monitored continuously using thermocouples. The humidifier temperature is maintained at a constant setpoint value using feedback control. Since the vapor pressure of the water and the resulting partial pressure of the steam exiting the humidifier are determined by the water bath temperature, the water vapor mass flow rate is directly proportional to the carrier gas flow rate for a specified bath temperature. Also, since the nitrogen and hydrogen flow rates are fixed by the mass flow controllers, and the steam partial pressure is fixed by the bath temperature, the complete gas composition is precisely known at all times. All gas lines located downstream of the humidifier are heat-traced in order to prevent 


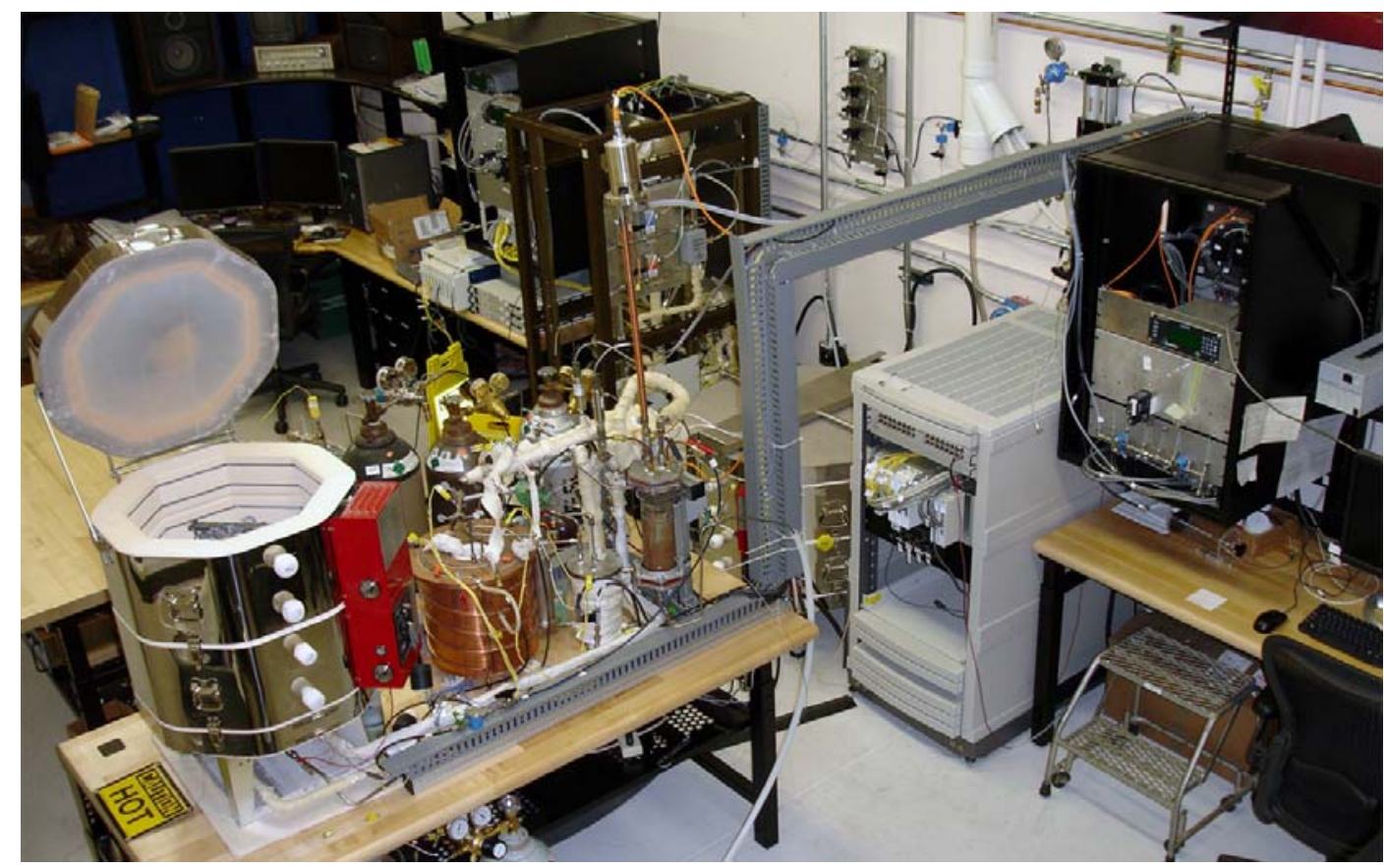

Figure 2. High-temperature electrolysis hardware.

steam condensation. Gas line temperatures are monitored by thermocouples and controlled by means of variable transformers or SCRs.

During system cool-down, it is desirable to maintain nitrogen and hydrogen gas flows. In order to allow for the flow of a dry nitrogen / hydrogen mixture through the system during cooldown without any possibility of steam condensation, a humidifier bypass was incorporated into the gas flow lines. Humidifier bypass is achieved by closing the shut-off valve in the bubbler line and changing the position of the 3-way valve located at the inlet to the first dewpoint measurement station (see Fig. 1). The humidifier also incorporates a pressure relief valve to avoid any possibility of over-pressurization.

The inlet dewpoint measurement station is located immediately downstream of the humidifier. This measurement station consists of a stainless-steel vessel that houses the dewpoint sensor head and a temperature probe. The sensors and the inlet and outlet gas lines are connected to the vessel using compression fittings. The outside of the vessel is fitted with a clamp heater and maintained at a temperature above the gas mixture dewpoint value at all times using feedback control. The outlet dewpoint measurement station is identical to the inlet station.

A close-up photograph of a 10-cell solid-oxide electrolysis stack is shown in Fig. 3. The stacks are fabricated by Ceramatec, Inc. of Salt Lake City, UT. This stack has a per-cell active area of $64 \mathrm{~cm}^{2}$. It is designed to operate in cross flow, with the steam / hydrogen gas mixture entering the inlet manifold on the right in the photograph, and exiting through the outlet manifold, visible on the left in the photograph. Air flow enters at the rear though an air inlet manifold (not visible in Fig. 3) and exits at the front directly into the furnace. The power lead attachment tabs, integral with the upper and lower interconnect plates are also visible in the photograph. Stack operating voltages were measured using wires that were directly spot-welded onto these tabs. 
Since the stack air outlet face is open, the small air flow channels are accessible for instrumentation. Four intermediate cell voltages are typically monitored by using small-diameter wires inserted into these air flow channels. In addition, miniature thermocouples can be inserted into the air flow channels to monitor internal stack temperatures. These thermocouples are inconel-sheathed, 0.020-inch $(500 \mu \mathrm{m})$ OD, mineralinsulated, ungrounded, type-K thermocouples.

The internal components of the

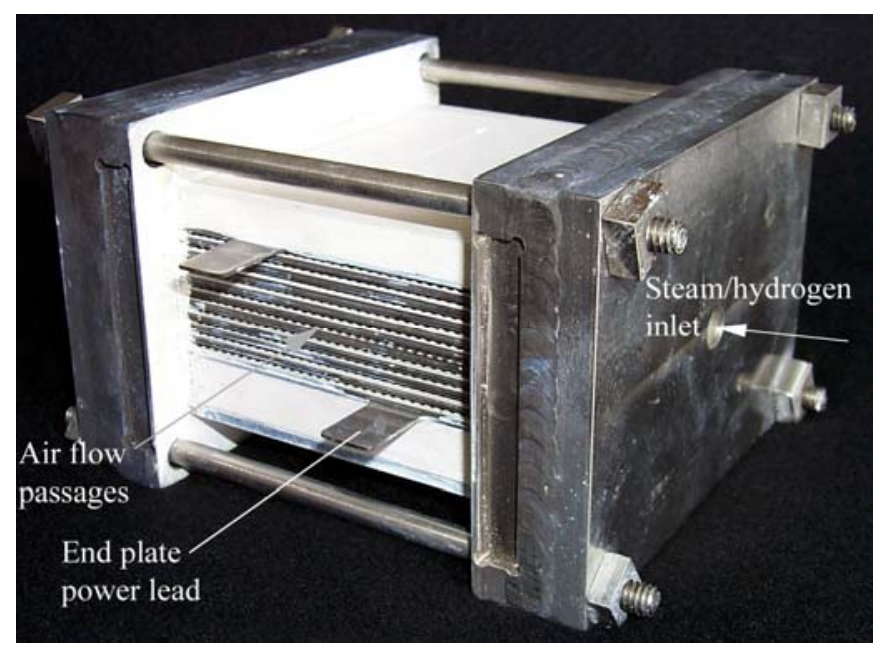

Figure 3. Detail of 10-cell stack. stack are shown in Fig. 4. It includes an impermeable separator plate ( $\sim 0.46 \mathrm{~mm}$ thick) with edge rails and two corrugated "flow fields," one on the air side and one on the steam/hydrogen side. The separator plate is fabricated from ferritic stainless steel alloy 441 or Crofer 22. The height of the flow channel formed by the edge rails and flow fields is $1.0 \mathrm{~mm}$. Each flow field includes 32 perforated flow channels across its width to provide uniform gas-flow distribution. The steam/ hydrogen flow field (visible in Fig. 4) is fabricated from nickel foil. The air-side flow field is ferritic stainless steel or Hastalloy X. The interconnect plates and flow fields also serve as electrical conductors and current distributors. To improve performance, the air-side separator plates and flow fields are pre-surface-treated to form a rare-earth conductive oxide scale. A perovskite rare-earth coating is also applied to the separator-plate oxide scale by either screen printing or plasma spraying. On

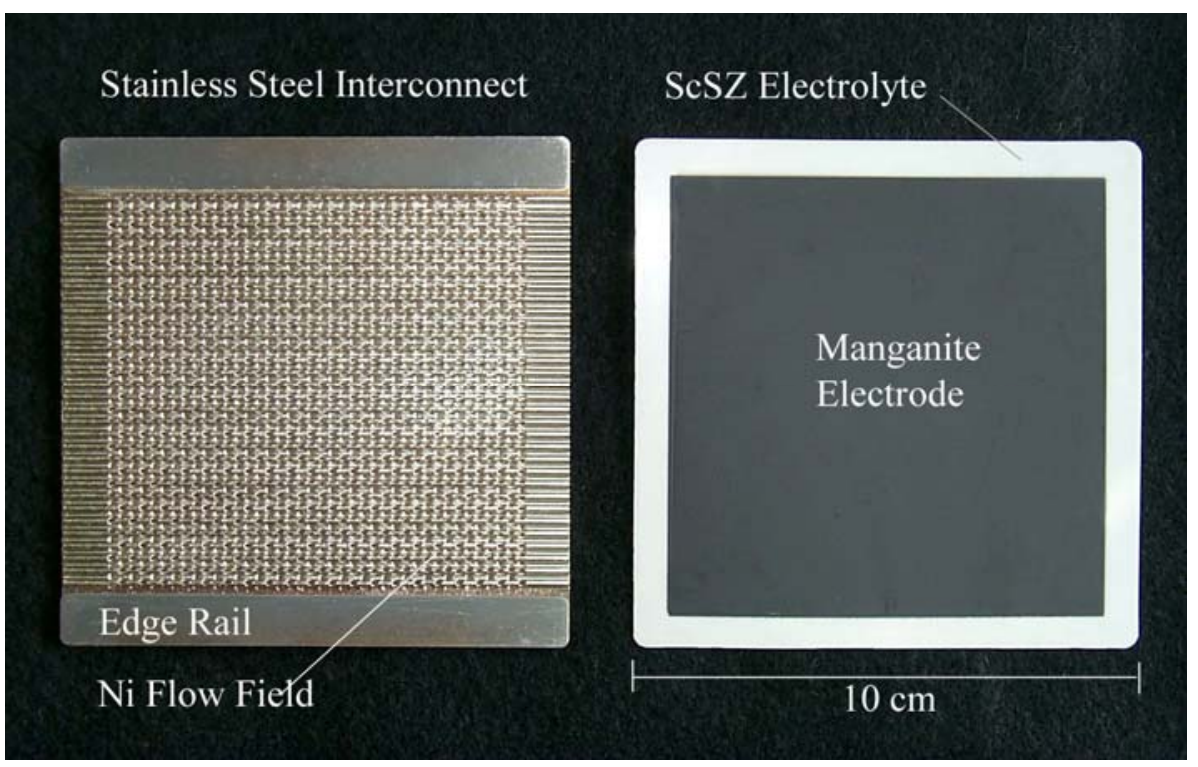

Figure 4. Interconnect plate and single electrolysis cell. 
1st cathode layer, LSM with

YSZ or ScSZ, $13 \mu \mathrm{m}$ thick

Cathode bond layer, cobaltite, $10 \mu \mathrm{m}$ thick

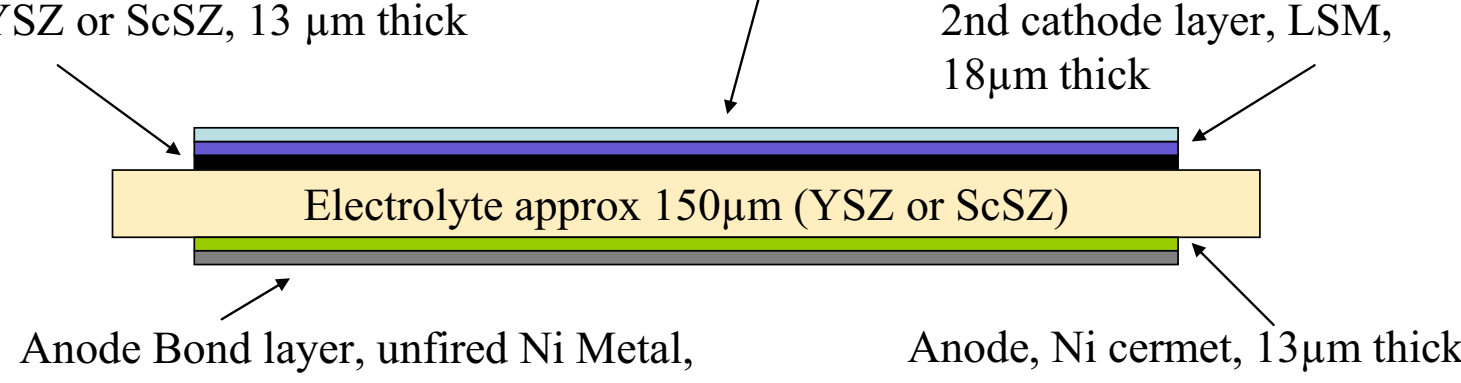
$10 \mu \mathrm{m}$ thick

Figure 5. Cross section of Ceramatec cell geometry.

the steam/hydrogen side of the separator plate, a thin $(\sim 10 \mu \mathrm{m})$ nickel metal coating is applied.

The electrolyte/electrode assembly is shown on the right of Fig. 4. A cross section of the cell is depicted schematically in Fig. 5. The electrolyte is scandia-stabilized zirconia, about $150 \mu \mathrm{m}$ thick. The air-side electrode (anode in the electrolysis mode), visible in the figure, is a strontium-doped manganite such as LSM. The electrode is graded, with an inner layer of manganite/ zirconia $(\sim 13 \mu \mathrm{m})$ immediately adjacent to the electrolyte, a middle layer of manganite $(\sim 18 \mu \mathrm{m})$, and an outer bond layer of cobaltite. The steam/ hydrogen electrode (cathode in the electrolysis mode) is also graded, with a nickel- cermet layer $(\sim 13 \quad \mu \mathrm{m})$ immediately adjacent to the electrolyte and a pure nickel outer layer $(\sim 10 \mu \mathrm{m})$.

A photograph of the stack, mounted on its inconel test fixture, and resting on the furnace base, is shown in Fig. 6. The power leads inside the furnace are inconel rods $(0.32 \mathrm{~cm} \mathrm{OD})$ insulated with alumina tubing. The hydrogen/ steam and air inlet tubes are coiled to provide additional length for heat transfer upstream of the stack. The furnace used for stack testing is an electrically heated pottery kiln (Skutt Model KS818-3), capable of maintaining temperatures up to $1250^{\circ} \mathrm{C}$. For the electrolysis application, it was configured to allow feedback temperature control, via the system controller computer. Electrolysis testing was performed in the temperature range of $800-900^{\circ} \mathrm{C}$.

Measurement of the outlet dewpoint temperature, downstream of the electrolysis stack, allows for direct determination of the change in dewpoint, the rate of steam reduction

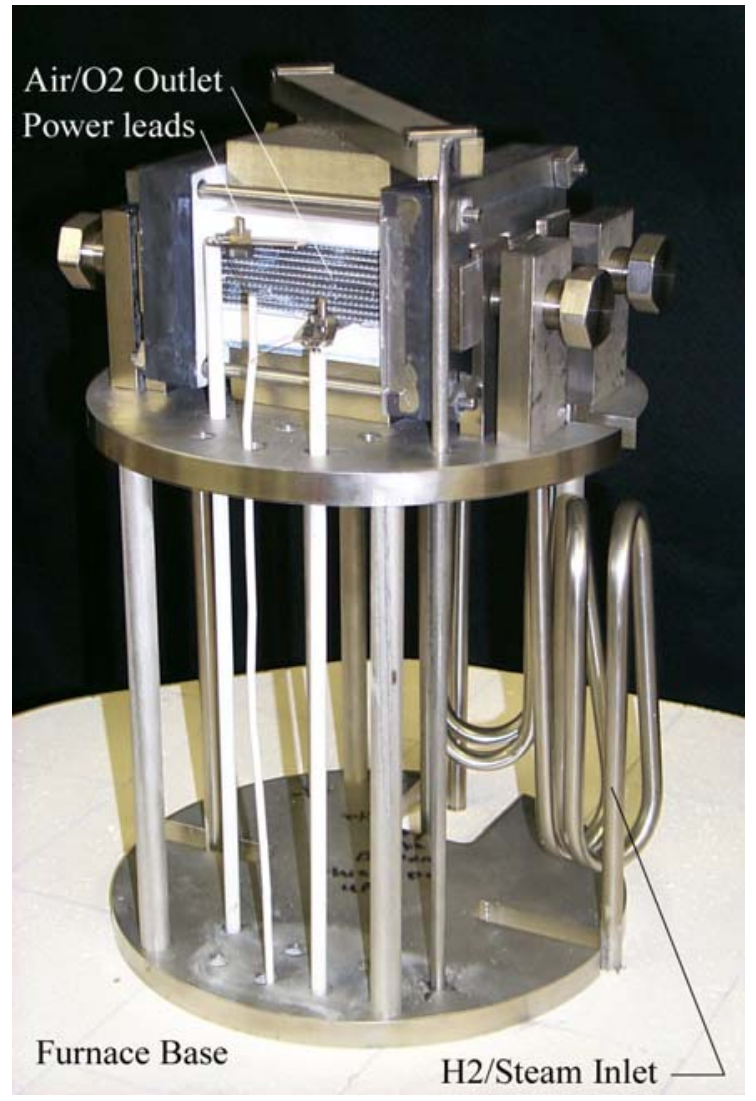

Figure 6. Ten-cell stack mounted on fixture for testing at INL. 
and the corresponding rate of hydrogen production during electrolysis testing. All testing is performed at essentially ambient laboratory pressure, about $85 \mathrm{kPa}$ for our $4700 \mathrm{ft}$. elevation.

Stack voltage and current values are controlled by means of a programmable DC power supply (Lambda Zup 20-40), rated for $20 \mathrm{~V}$ and 40 amps. The power supply can be operated in either the constant-current or constant voltage modes. This power supply is interfaced to the system controller computer via an RS232 interface. Cell amperage and the voltage across the stack are monitored continuously. Stack current measurements are obtained from the power supply, with redundant measurements provided by a precision shunt $(50 \mathrm{~A}=200 \mathrm{mV})$. Temperature and humidity signals from the humidity measurement stations were wired directly into two dewpoint transmitter electronics units (Vaisala Model HMP247). These units were also interfaced to the system controller computer via an RS232 interface.

Signals from all thermocouple channels, mass-flow controllers, pressure transducer, and stack voltage taps were wired into a modular data acquisition system (National Instruments Model SCXI) which was configured for this application with a 32-channel analog input module and an eight-channel analog output module. The analog output module was used to provide control signals $(4-20 \mathrm{~mA})$ for feedback temperature control of the humidifier, the humidity measurement stations, and the furnace. Data acquisition and instrument control were implemented for these tests using a LabView (National Instruments) program (virtual instrument) specifically created for this experiment. Temperature control of the humidifier, the humidity sensing volumes, and the furnace was accomplished using customized PID control algorithms.

\subsection{Short Stack HTE Test Procedure}

Prior to each test, a slow automated heat-up of the electrolysis stack is performed with the stack in the open-cell condition until the desired test temperature is achieved. A heating time of 12 hours is typically used to take the stack from room temperature to $800^{\circ} \mathrm{C}$. During this time, the humidifier, humidity sensing station, and heat tracing temperatures are also established. Nitrogen, hydrogen, and air gas flow rates are established for the heatup by adjusting the set points on the mass-flow controller electronics unit. The humidifier temperature desired for postheatup testing is also established at this time. Data recording is initiated at the start of the heatup in order to document process details and to track the stack open-cell potential. Theoretical opencell potentials can be predicted from the Nernst equation for any given gas composition as a function of temperature. Comparison of measured and predicted open-cell potential values during heat-up provides a useful system diagnostic. A significant departure of measured opencell potential from the predicted value can indicate a problem such as a cracked cell or leakage. Some small leakage is expected for the stack configuration, however.

Two types of stack characterization tests will be performed: DC potential sweeps and steadystate long-term operation. DC potential sweeps are performed by programming the power supply to vary the applied stack voltage over a range, typically from $8 \mathrm{~V}$ to $18 \mathrm{~V}$ for a ten-cell stack. Applied voltage values lower (in magnitude) than the open-cell potential $(\sim 0.9 \mathrm{~V} /$ cell) yield the fuel-cell mode of operation while applied voltages higher than the open-cell value yield electrolysis. The sweep rate for these tests is set to about $8 \mathrm{mV} / \mathrm{s}$, so each sweep requires a total time of about 25 minutes. Results of the DC potential sweeps allow for determination of the stack area-specific resistance and hydrogen production rates. These sweeps can be carried out immediately after the stack has reached the operating temperature (typically $800^{\circ} \mathrm{C}$ ) and at selected times during long-term testing. Long-term tests are performed by selecting an 
appropriate stack operating voltage and observing the hydrogen-production performance over a relatively long period of time, to document the degradation in performance that occurs over the long term.

\section{TEST CONDITIONS FOR 2500 HOUR LONG-TERM TEST}

\section{Stack details:}

Cell Size:

$10 \mathrm{~cm} \times 10 \mathrm{~cm}$

Active Area:

$8 \mathrm{~cm} \times 8 \mathrm{~cm}\left(64 \mathrm{~cm}^{2}\right)$

Cell composition:

Number of cells:

Interconnect:

see Fig. 5 and associated text description

ten

Flow Fields:

Crofer 22 (based on preliminary assessment of FY08 test series results)

Coatings: nickel on steam-hydrogen side, Hastalloy $\mathrm{X}$ on air side TBD, based on results of current test series

\section{Initial Heatup:}

initial temperature: $\quad 20^{\circ} \mathrm{C}$

final temperature: $\quad 800^{\circ} \mathrm{C}$

heatup time: $\quad 12 \mathrm{hrs}$.

Table 1. Heatup gas flow rates.

\begin{tabular}{|l|c|c|c|c|}
\hline & $\begin{array}{c}\text { cathode side } \\
20-400^{\circ} \mathrm{C}\end{array}$ & $\begin{array}{c}\text { anode side } \\
20-400^{\circ} \mathrm{C}\end{array}$ & $\begin{array}{c}\text { cathode side } \\
400-800^{\circ} \mathrm{C}\end{array}$ & $\begin{array}{c}\text { anode side } \\
400-800^{\circ} \mathrm{C}\end{array}$ \\
\hline $\mathrm{sccm} \mathrm{N}_{2}$ & 0 & 0 & 800 & 0 \\
\hline $\mathrm{sccm} \mathrm{H}_{2}$ & 0 & 0 & 800 & 0 \\
\hline $\mathrm{sccm}$ air & 1000 & 5000 & 0 & 5000 \\
\hline $\mathrm{T}_{\mathrm{dpi}}$ & dry & dry & dry & dry \\
\hline
\end{tabular}

\subsection{TEST STARTUP SEQUENCE}

The following is the sequence of steps to be followed by the researchers for initial heatup and testing.

1. Walk down system.

2. Conduct pre-test briefing.

3. Connect hydrogen and nitrogen cylinders to system. Check output pressures of cylinders. Replace cylinders if necessary.

4. Put into position all necessary warning signs and administrative barriers.

5. Notify all personal in bay that testing is about to commence.

6. Check that electrolyzer power switch is in the neutral (open-cell) position.

7. Turn on all necessary power supplies.

8. Turn on mass flow controller power supply/read out units.

9. Check DACS values for thermocouples and voltages/currents. 
10. Start flow of cooling water to condenser.

11. Ensure water levels in humidifier and condenser are appropriate.

12. Set three-way valve to humidifier bypass position.

13. Initiate data recording.

14. Initiate air gas flows to anode and cathode sides using early heatup values (see Table 1).

15. Execute early heatup to $400^{\circ} \mathrm{C}$.

16. Begin very gradual increase of humidifier setpoint temperature to $80^{\circ} \mathrm{C}$.

17. Purge hydrogen side of stack with pure nitrogen for approximately 10 minutes.

18. Initiate hydrogen and nitrogen gas flows to later heatup values (see Table 1) - cathode side.

19. Perform remainder of heatup to $800^{\circ} \mathrm{C}$.

20. Gradually increase setpoint temperatures for inlet and outlet dewpoint sensor vessels from room temperature to $110^{\circ} \mathrm{C}$.

21. Increase setpoint temperature of heat trace to ultimately to $110^{\circ} \mathrm{C}$.

22. Set hydrogen, nitrogen and air flow rates to final test values (Table 2). Ensure that humidifier temperature is at $80^{\circ} \mathrm{C}$. Set three-way valve to direct the nitrogen $/$ hydrogen flow through the humidifier.

23. Once the system is at steady state nominal conditions, check stack open cell potential against the theoretical value.

24. Set stack power supply to open cell potential measured above. Close circuit between power supply and stack. Verify via current shunt measurement that the stack current remains near zero after engaging power supplies. If current values differ significantly from zero, immediately disengage power supply and return modules to open cell condition.

25. Adjust power supply voltage to slightly above open cell, e.g , $1.0 \mathrm{~V}$ per cell (10 volts total). Observe current and module ASR values.

26. Initiate voltage sweeps up to the thermal neutral voltage, or slightly beyond.

27. Establish long duration operating condition. Adjust power supply until the target current density is acquired $\left(\sim 12.8 \mathrm{~V}\right.$ for $\mathrm{I}=0.25 \mathrm{~A} / \mathrm{cm}^{2}$ and $\left.\mathrm{ASR} \sim 1.5 \mathrm{Ohm} \cdot \mathrm{cm}^{2}\right)$.

28. Initiate long-term stack operation at steady-state constant-voltage condition. Adjust data acquisition write-to-disk rate for lower data record rate. Start new data file.

29. Periodically during long duration testing, check open-cell potential and perform fast or slow voltage sweeps on modules. 
3.2. TEST MATRIX (based on estimated per-cell ASR value of $1.5 \mathrm{Ohm} \cdot \mathrm{cm}^{2}$ )

Table 2. Operating conditions for initial sweeps and long-term testing.

\begin{tabular}{|l|c|}
\hline Controlled parameters & \\
\hline current density, $\mathrm{A} / \mathrm{cm}^{2}$ & 0.25 \\
\hline Inlet dewpoint, ${ }^{\circ} \mathrm{C}$ & 80 \\
\hline Inlet $\mathrm{N}_{2}$ flow rate, $\mathrm{sccm}$ & 1370 \\
\hline Inlet $\mathrm{H}_{2}$ flow rate, $\mathrm{sccm}$ & 400 \\
\hline Inlet air flow rate, $\mathrm{sccm}$ & 1000 \\
\hline & \\
\hline Resultant parameters & 1114 \\
\hline $\mathrm{H}_{2}$ production rate, sccm & 56 \\
\hline Inlet steam mole fraction, $\%$ & 10 \\
\hline Inlet hydrogen mole fraction, $\%$ & 34 \\
\hline Inlet nitrogen mole fraction, $\%$ & 50 \\
\hline steam utilization, $\%$ & 63.8 \\
\hline outlet dewpoint, ${ }^{\circ} \mathrm{C}$ & 0.858 \\
\hline Open-cell potential, $\mathrm{V} / \mathrm{cell}$ & 1.28 \\
\hline Operating Voltage (assume ASR 1.5), V/cell & 205 \\
\hline Total Stack Power, $\mathrm{W}$ & \\
\hline & \\
\hline
\end{tabular}

\section{REFERENCES}

1. Sohal, M. S., O’Brien, J. E., Soots, C. M., McKellar, M. G., and Herring, J. S., "Challenges in Generating Hydrogen by High Temperature Electrolysis using Solid Oxide Cells," National Hydrogen Association Annual Hydrogen Conference 2008, March 30- April 3, 2008, Sacramento. 